\title{
Record of the sarcophagid flies (Diptera, Sarcophagidae) from Vietnam
}

\author{
Satoshi ShinonagA ${ }^{1)}$ and Ta Huy ThinH ${ }^{2)}$ \\ 1) Division of Environmental Parasitology, Graduate School, Tokyo Medical and \\ Dental University, 1-5 Yushima, Bunkyo-ku, Tokyo 113-8519, Japan \\ ${ }^{2)}$ Department of Insect Systematics, Institute of Ecology and Bioresources, \\ NCNST, Nghia Do, Cau Giay, Hanoi, Vietnam
}

(Received: 4 April 2003; Accepted: 6 August 2003)

\begin{abstract}
Three subfamilies, three genera and 19 species of the sarcophagid flies collected by the authors during the survey of Monbusho International Co-operation Scientific Program in Vietnam are recorded. Three new species, Sarcophaga (Lioproctia) vietnamensis sp. nov., S. (Parasarcophaga) owadai sp. nov. and S. (Parasarcophaga) dambriensis sp. nov. are described and figured. Sarcophaga (Phallosphaera) konakovi (Rohdendorf), S. (Robineauella) anchoriformis (Fan), Senotainia albifrons (Rondani) and S. navigatrix (Meigen) are newly recorded from Vietnam.
\end{abstract}

Key words: Sarcophagidae, Vietnam, new species, new record

\section{INTRODUCTION}

Kano et al. (1999) reported 32 sarcophagid species from the northern part of Vietnam. Among them, 19 species were new records. Afterwards, the authors joined Monbusho International Co-operation Scientific Program by the National Science Museum, Tokyo and Institute of Ecology and Bioresources, NCNST, Vietnam in 2002. The present paper is a part of the result and records 16 sarcophagid species collected during the survey, including 3 new and 4 newly recorded species. Systematics of Sarcophagidae followed Pape (1996).

\section{Subfamily MILTOGRAMMATINAE}

\section{Miltogramma angustifrons}

(Townsend, 1933)

Specimens examined: 1우, Dambri, 15 km NW Bao Loc, Lam Dong Prov., 29 May-1 June 2002, S. Shinonaga.
Miltogramma ibericum Villeneuve, 1912

Specimen examined: 1 우, Dambri, 15 km NW Bao Loc, Lam Dong Prov., 29 May-1 June 2002, S. Shinonaga; 1 우, Cuc Phuong, $120 \mathrm{~km}$ SW of Hanoi, Ninh Binh Prov., 13-14 June 2002, T. H. Thinh; 1 우, Bach Ma, Thua Thien Hue Prov., 7-11 June 2002, S. Shinonaga; 1 우, Bach Ma, Thua Thien Hue Prov., 7-11 June 2002, T. H. Thinh.

Senotainia albifrons (Rondani, 1859)

Specimen examined: 1우, Bach $\mathrm{Ma}$, Thua Thien Hue Prov., 7-11 June 2002, S. Shinonaga (new record from Vietnam).

Senotainia navigatrix (Meigen, 1919)

Specimens examined: 1 우, Dambri, 15 km NW Bao Loc, Lam Dong Prov., 29 May-1 June 2002, S. Shinonaga; $10^{7}$, Deo Cao Pha, E. of Ban Song, Son La Prov., 7 June 1999, H. Kurahashi; 1 우, Deo Pha Din, Son La Prov., 6 June 1999, H. Kurahashi; 
1 우, Pa Ham Waterfall, Muong Lay, Lai Chau Prov., 5 June 1999, H. Kurahashi (new record from Vietnam).

\section{Subfamily SARCOPHAGINAE}

\section{Sarcophaga (Phallosphaera) gravelyi Senior-White, 1924}

Specimens examined: $810^{\top}$, Bach Ma, Thua Thien Hue Prov., 7-11 June 2002, S. Shinonaga; $8 \sigma^{\text {T }}$, ditto, 5 May 2003, T. H. Thinh.

\section{Sarcophaga (Phallosphaera) konakovi} (Rohdendorf, 1938)

Specimens examined: $80^{7}$, Bach Ma, Thua Thien Hue Prov., 7-11 June 2002, S. Shinonaga; $1 \sigma^{\top}$, ditto, 5 May 2003, T. H. Thinh (new record from Vietnam).

\section{Sarcophaga (Boettcherisca) nathani (Lopes, 1961)}

Specimens examined: $4 \sigma^{7}$, Bach Ma, Thua Thien Hue Prov., 7-11 June 2002, S. Shinonaga; $1 \sigma^{\nearrow}$, Cuc Phuong, $120 \mathrm{~km} \mathrm{SW}$ of Hanoi, Ninh Binh Prov., 13-14 June 2002, S. Shinonaga; $1 \sigma^{\text {T }}$, Tam Dao Nat. Park, 900-1,200 m, Vinh Phu Prov., 13 May 2003, T. H. Thinh.

\section{Sarcophaga (Boettcherisca) peregrina}

(Robineau-Desvoidy, 1830)

Specimen examined: $1 \sigma^{7}$, Bach Ma, Thua Thien Hue Prov., 7-11 June 2002, S. Shinonaga.

\section{Sarcophaga (Seniorwhitea) princeps Wiedemann, 1830}

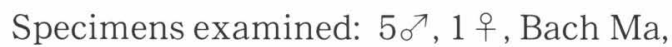
Thua Thien Hue Prov., 7-11 June 2002, S. Shinonaga; $7 \sigma^{7}$, ditto, T. H. Thinh; $1 \sigma^{\nearrow}$, Bao Loc, 800 m, Lamg Prov., 27 May 2003, T. H. Thinh.

\section{Sarcophaga (Harpagophalla) kempi Senior-White, 1924}

Specimen examined: $1 \sigma^{\top}$, Cuc Phuong, $120 \mathrm{~km}$ SW of Hanoi, Ninh Binh Prov., 1314 June 2002, S. Shinonaga.

\section{Sarcophaga (Parasarcophaga) albiceps (Meigen, 1826)}

Specimens examined: $11 \sigma^{7}$, Bach Ma, Thua Thien Hue Prov., 7-11 June 2002, S. Shinonaga; $190^{\nearrow}$, ditto, T. H. Thinh; $1 \sigma^{\top}$, ditto, 7 May 2003, T. H. Thinh; $40^{7}$, Tam Dao Nat. Park, 900-1,200 m, Vinh Phu Prov., 13 May 2003, T. H. Thinh.

\section{Sarcophaga (Parasarcophaga) javana Macquart, 1851}

Specimens examined: $16 \sigma^{\top}$, Bach Ma, Thua Thien Hue Prov., 7-11 June 2002, S. Shinonaga; $13 \sigma^{\top}$, ditto, T. H. Thinh; $4 \sigma^{\top}$, ditto, 1,300 m, 5 May 2003, T.H. Thinh; $3 \sigma^{7}$, Tam Dao Nat. Park, 900-1,200 m, Vinh Phu Prov., 13 May 2003, T. H. Thinh.

\section{Sarcophaga (Parasarcophaga) taenionata}

(Wiedemann, 1819)

Specimen examined: $1 \sigma^{\nearrow}$, Cuc Phuong, 120 km SW of Hanoi, Ninh Binh Prov., 1314 June 2002, S. Shinonaga.

\section{Sarcophaga (Parasarcophaga) yunnanensis (Fan, 1964)}

Specimens examined: $6 \sigma^{7}$, Dambri (800 m), 15 km NW. Bau Lok, 20 May-1 June 2002, S. Shinonaga; $2 \sigma^{\top}$, Cuc Phuong, 120 km SW of Hanoi, Ninh Binh Prov., 13-14 June 2002, S. Shinonaga; $2 \sigma^{\nearrow}$, Bach Ma, Thua Thien Hue Prov., 7-11 June 2002, S. Shinonaga. 


\section{Sarcophaga (Parasarcophaga) dambriensis sp. nov.} (Fig. 1)

Male. Body length about $10 \mathrm{~mm}$.
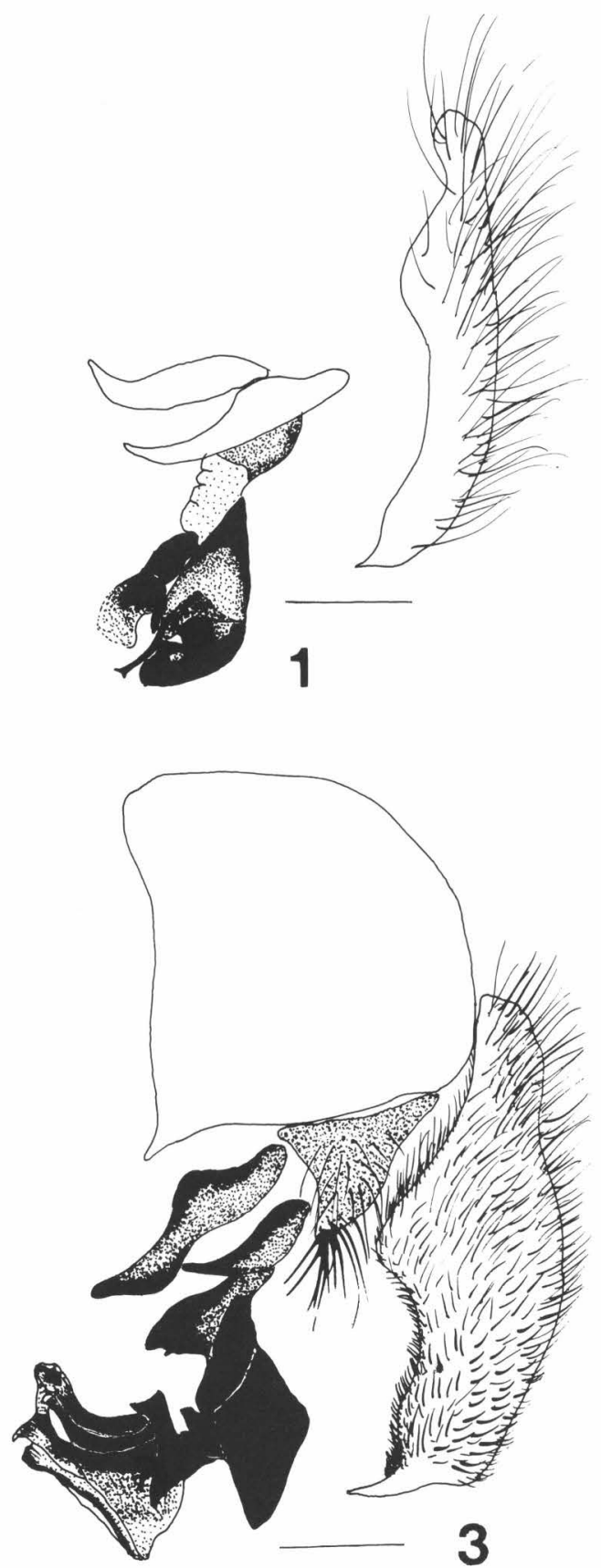

Head: Eyes bare; frons open, at narrowest point about 0.25 of head width; frontal vitta black with grayish dust, parallel sided; parafrontals black with grayish pollen; frontal bristles 10 to 11, upper 2 or 3 reclinate; antennae black, arista feathered; palpi black; genae black, about
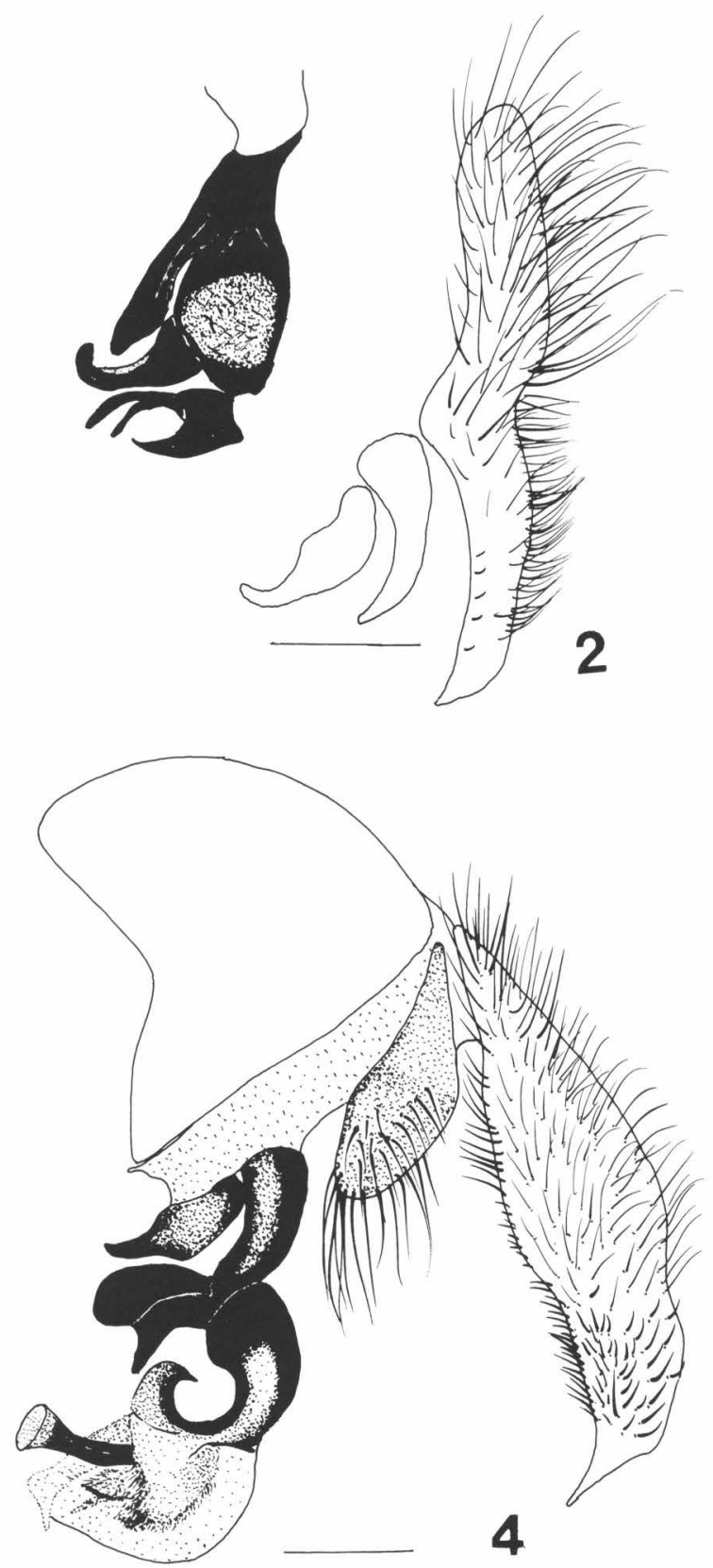

Figs. 1-4. Male genitalia. 1, Sarcophaga (Parasarcophaga) dambriensis sp. nov.; 2, Sarcophaga (Parasarcophaga) owadai sp. nov.; 3, Sarcophaga (Lioproctia) vietnamensis sp. nov.; 4, Sarcophaga (Mehria) suthep Pape et Banziger. Scale: $1.0 \mathrm{~mm}$. 
0.22 of eye heights; genal hairs black; metacephalon with white hairs.

Thorax: Scutum black with grayish pollen and 3 dark longitudinal stripes; preacrostichal bristles differentiated, prescutellar acrostichal bristle 1 ; dc $5+5$; ia $1+3$; $h$ 3; ph 2; scutellar bristles developed, 2 laterals, 1 preapical, 1 or 2 discals; st $1+1+1$; propleuron bare; meso- and metathoracic spiracles dark brown.

Wings: Hyaline; $r_{1}$ bare; $r_{4+5}$ setose on basal $5 / 8$ of distance to cross vein.

Legs: Black; $t_{1}$ with $p$-seta; ventral hairs on $t_{3}$ shorter than av seta.

Abdomen: Black with checkered pattern; 1st sternite hairy; 2nd and 3rd sternites with numerous long hairs; genitalia as shown in figure 1.

Female. Unknown.

Holotype. व $\sigma^{7}$, Dambri, 800 m, 15 km NW of Bao Lok, 29 May-1 June 2002, S. Shinonaga.

Remark. It differs from the other species of the same subgenus especially by the structure of male genitalia.

\section{Sarcophaga (Parasarcophaga) owadai}

sp. nov.

(Fig. 2)

Male. Body length about $11 \mathrm{~mm}$.

Head: Eyes bare; frons open, narrowest point about 0.25 of head width; frontal vitta black with grayish dust, slightly widened anteriorly; parafrontals broad, protruding at antennal base seen laterally with grayish pollen; frontal bristles 10, upper 2 reclinate; antennae black, arista feathered; palpus black; genae black, about 0.3 of eye heights; genal bristles black; metacephalon with white hairs.

Thorax: Scutum black with grayish pollen and 3 dark longitudinal stripes; $a c 0+1 ; d c 6$ (small) +5 ; ia $1+2 ; h 3$; ph 2; scutellar bristles developed, 2 laterals, 1 preapical, 1 discals; st 1 +2 ; propleuron bare; notopleuron hairy; mesoand metathoracic spiracles dark brown.

Wing: Hyaline; $r_{1}$ bare; $r_{4+5}$ setose on basal $1 / 4$ of distance to cross vein.

Legs: Black; $t_{1}$ with $p$-seta; $t_{3}$ with long hairs curled at apices on $a v$ and $p v$ surfaces.

Abdomen: Black with checkered pattern; 1st sternite hairy; 2nd and 3rd sternites with numerous long hairs; genitalia as shown in figure 2.
Female. Unknown.

Holotype. 万人, Bach Ma, 1,000-1,200 m, Thua Thien Hue Prov., 7-11 June 2002, T. H. Thinh.

Remark. The species differs from other related species of the subgenus in the characteristic structure of phallosome and broad parafrontals.

\section{Sarcophaga (Robineauella) anchoriformis} (Fan, 1964)

Specimen examined: $1 \sigma^{7}$, Bach Ma, Thua Thien Hue Prov., 7-11 June 2002, S. Shinonaga; 10 , Sapa, 1,800-2,000 m, 25 $\mathrm{km}$ NE of Lao Cai, 17 May 2003, T. H. Thinh (New record from Vietnam).

\section{Sarcophaga (Lioproctia) vietnamensis sp. nov.}

(Fig. 3)

Male. Body length 10-12 mm.

Head: Eye bare; frons open, narrowest point about 0.21 of head width; frontal vitta black with grayish dust, parallel sided; parafrontals black with golden pollen; frontal bristles 9 to 10 , upper 2 reclinate; antenna black, length of 3 rd segment about 4 times that of the 2 nd; arista feathered; palpus black; gena black, about 0.33 of eye heights; genal bristles black; metacephalon with white hairs.

Thorax: Scutum black with grayish pollen and 3 dark longitudinal stripes; $a c 0+1 ; d c 5+$ 4; ia $1+3 ; h$ 3; ph 2; scutellar bristles developed, 2 laterals, 1 preapical, 1 discals; st $1+1+1$; propleuron bare; notopleuron hairy; meso- and metathoracic spiracles dark brown.

Wing: Hyaline; $r_{1}$ bare; $r_{4+5}$ setose on basal $3 / 4$ of distance to cross vein.

Legs: Black; $t_{1}$ with $p$-seta; $t_{3}$ with long hairs on distal $3 / 5$ of $a v$ and $p v$ surfaces.

Abdomen: Black with checkered pattern; 3rd tergite with median marginal bristles; 1 st sternite hairy; 2nd and 3rd sternites with numerous long hairs; cerci broad and pointed apically; genitalia as shown in figure 3 .

Female. Unknown.

Holotype. $0^{7}$, Bach Ma, 1,000-1,200 m, Thua Thien Hue Prov., 7-11 June 2002, S. Shinonaga.

Paratypes. $6 \sigma^{\nearrow}$, same data as holotype; 
$10^{7}$, ditto, 500 m, 7 May 2003, T. H. Thinh. Remarks. The species is closely related to S. (Phallosphaera) kurahashii Shinonaga and Tumrasvin (1979) from Thailand in the external characters, however, the shape of phallosome is remarkably different. Shinonaga and Tumrasvin included S. kurahashii in subgenus Phallosphaera, but $S$. kurahashii has no conical protuberance on 5th sternite which is a typical character of the subgenus, therefore, this species does not belong to Phallosphaera, but Lioproctia.

\section{Sarcophaga (Rosellea) suthep}

Pape et Banziger, 2003 (Fig. 4)

Specimens examined: $100^{\top}$, Bach Ma, 1,000-1,200 m, Thua Thien Hue Prov., 711 June 2002, S. Shinonaga.

Remarks. The present species is recorded as Parasarcophaga aratrix by Kano et al. (1999), however, this was considered to be misidentification (Pape and Banziger, 2003).

\section{ACKNOWLEDGEMENTS}

The authors express their sincere thanks to Dr. H. Kurahashi for identification of the species belonging to the Miltogrammatinae. We express our sincere gratitude to Dr. M. Owada, team leader of the expedition of National Science Museum,
Tokyo for offering an opportunity to survey in Vietnam. We wish to also express our hearty thanks to the following scientists, officials and institutes for their kind aid in the field researches of our joint project on the insect fauna of Vietnam: Director Dr. Vu Quang Con, Assoc. Prof. Dr. Le Xuan Canh, Dr. Le Xuan Hue, Mr. Dang Duc Khuong and Mr. Hoan Vu Tru (IEBR); Dr. Ha Quang Hung and Dr. Tran Dinh Chien (HAU); Head quarters of Bach $\mathrm{Ma}$, Cuc Phuong and $\mathrm{Ba} \mathrm{Be}$ National Parks, for their king advice and support.

This study is supported by a Grant-inAid No. 13575015 for Field Research of the Monbusho International Scientific Research Program, Japan.

\section{REFERENCES}

Kano, R., Thinh, T.H. and Kurahashi, H. 1999. The flesh flies (Diptera, Sarcophagidae) from the northern part of Vietnam. Bull. Nat. Sci. Mus., Tokyo, (A), 25: 129-141.

Pape, T. 1996. Catalogue of the Sarcophagidae of the world (Insecta, Diptera). Mem. Entomol. Inst., 8: 1558.

Pape, T. and Banziger, H. 2003. Three new species of Sarcophaga Meigen found during ecological studies on flesh flies (Diptera: Sarcophagidae) in Thailand. Entomol. Sci., 6: 49-56.

Shinonaga, S. and Tumrasvin, W. 1979. Two new genera and ten new species of the sarcophagid flies from Thailand (Diptera: Sarcophagidae). Jpn. J. Sanit. Zool., 30: 135-145. 